\title{
Role of L-arginine in the deficiency of nitric oxide and airway hyperreactivity after the allergen-induced early asthmatic reaction in guinea-pigs
}

\author{
${ }^{*, 1}$ Jacob de Boer, ${ }^{1}$ Michiel Duyvendak, ${ }^{1}$ Fineke E. Schuurman, ${ }^{1}$ F. May H. Pouw, ${ }^{1}$ Johan Zaagsma \& \\ ${ }^{1}$ Herman Meurs
}

${ }^{1}$ Department of Molecular Pharmacology, University Centre for Pharmacy, A. Deusinglaan 1, 9713 AV Groningen, The Netherlands

1 Using a guinea-pig model of allergic asthma, we investigated the role of L-arginine limitation in the allergen-induced deficiency of nitric oxide (NO) and airway hyperreactivity (AHR) after the early asthmatic reaction, by examining the effects of various concentrations of the NO synthase (NOS) substrate on the responsiveness to methacholine of isolated perfused tracheae from unchallenged (control) animals and from animals $6 \mathrm{~h}$ after ovalbumin challenge.

2 Preparations from ovalbumin-challenged guinea-pigs showed a 1.9 fold increase in the maximal response $\left(\mathrm{E}_{\max }\right)$ to intraluminal (IL) administration of methacholine compared to controls $(P<0.001)$. A similar 2.0 fold $(P<0.05)$ increase in $\mathrm{E}_{\max }$ to methacholine was observed in control airways incubated with the NOS inhibitor $\mathrm{N}^{\omega}$-nitro-L-arginine methyl ester (L-NAME; $0.1 \mathrm{mM}, \mathrm{IL}$ ), while L-NAME had no further effect on the airways from ovalbumin-challenged animals.

3 In control airways, extraluminal (EL) administration of $0.3,1.0$ and $5.0 \mathrm{~mm}$ L-arginine all suppressed the $\mathrm{E}_{\max }$ for methacholine by approximately $40 \%(P<0.01$ all $)$, whereas $5.0 \mathrm{mM} \mathrm{D}-$ arginine (EL) had no effect.

4 L-Arginine dose-dependently reduced the AHR to methacholine in tracheae from ovalbuminchallenged guinea-pigs, the responsiveness being normalized in the presence of $5.0 \mathrm{mM}$ L-arginine. As in controls, $5.0 \mathrm{mM}$ D-arginine was without effect.

5 The results demonstrate that deficiency of endogenous NO contributes to the allergen-induced AHR to methacholine after the early asthmatic reaction, which is reversed by exogenous administration of L-arginine. This indicates that limitation of substrate may underly the reduced cNOS activity and subsequent AHR after the acute asthmatic response.

Keywords: L-arginine; $\mathrm{N}^{\omega}$-nitro-L-arginine methyl ester; nitric oxide; nitric oxide synthase; methacholine; tracheal perfusion; airway hyperreactivity; asthma; allergic guinea-pigs

Abbreviations: AHR, airway hyperreactivity; cNOS, constitutive nitric oxide synthase; EL, extraluminal; $\mathrm{E}_{\max }$, maximal effect; IL, intraluminal; iNOS, inducible nitric oxide synthase; KH, Krebs-Henseleit; L-NAME, $\mathrm{N}^{\omega}$-nitro-L-arginine methyl ester; MBP, major basic protein; NO, nitric oxide; $\Delta \mathrm{P}$, differential (hydrostatic) pressure; $\mathrm{pEC}_{50},-\log _{10}$ of the concentration causing $50 \%$ of effect; $\mathrm{P}_{\text {inlet }}$, (hydrostatic) pressure at the inlet; $\mathrm{P}_{\text {outlet }}$, (hydrostatic) pressure at the outlet

\section{Introduction}

Allergen-induced early and late asthmatic reactions (BooijNoord et al., 1971), infiltration and activation of inflammatory cells in the airways (De Monchy et al., 1985; Djukanovic et al., 1990) and an increase in airway reactivity (AHR) to nonspecific stimuli, both after the early and after the late asthmatic reaction (Cockroft et al., 1977; Durham et al., 1988), are important features of allergic asthma.

Endogenous nitric oxide (NO) plays a central role in the regulation of airway tone as well as in asthmatic airway inflammation (Barnes \& Belvisi, 1993; Gaston et al., 1994; Barnes \& Liew, 1995), and may be importantly involved in the development of allergen-induced AHR (De Boer et al., 1996; Schuiling et al., 1998a,b). Thus, NO has a potent bronchodilator action by inducing relaxation of airway smooth muscle (Gruetter et al., 1989; Dupuy et al., 1992), is an important immunomodulator by promoting the proliferation of Th2 lymphocytes (Barnes \& Liew, 1995), and, at high concentrations, may have deleterious effects in the airways by causing

\footnotetext{
*Author for correspondence.
}

mucosal swelling (Kuo et al., 1992) and epithelial damage (Flak \& Goldman, 1996).

$\mathrm{NO}$ is synthesized from the semi-essential amino acid Larginine by the enzyme NO synthase (NOS), of which different isoforms have been identified (Forstermann et al., 1991). Constitutive NOS isoforms (collectively called cNOS) are mainly expressed in inhibitory nonadrenergic noncholinergic nerves, endothelial cells and airway epithelium (Fischer et al., 1993; Kobzik et al., 1993; Asano et al., 1994), and are thought to be primarily involved in the regulation of airway and vascular tone by the local production of small amounts of NO in response to physiological stimuli (Barnes \& Belvisi, 1993). An inducible isoform of NOS (iNOS), producing large amounts of $\mathrm{NO}$, is induced by proinflammatory cytokines during airway inflammation, particularly in inflammatory and epithelial cells (Barnes \& Belvisi, 1993; Hamid et al., 1993; Asano et al, 1994), and may be involved in the detrimental effects described above.

Various observations have indicated the involvement of endogenous NO in the regulation of airway tone. Thus, in vitro studies have demonstrated that nonselective NOS inhibitors such as $\mathrm{N}^{\omega}$-nitro-L-arginine methyl ester (L- 
NAME) and $\mathrm{N}^{\mathrm{G}}$-monomethyl-L-arginine (L-NMMA) cause enhanced muscarinic agonist-, histamine- and substance Pinduced constriction of intact perfused guinea-pig tracheal tube preparations (Nijkamp et al., 1993; De Boer et al., 1996; Figini et al., 1997), while vasoactive intestinal peptide, endothelin-1 and bradykinin-induced relaxations were reduced in the presence of these inhibitors (Lilly et al., 1993; Filep et al., 1993; Figini et al., 1996). In vivo, inhaled NO reversed histamine and methacholine-induced bronchoconstriction in humans (Kacmarec et al., 1996), guinea-pigs (Dupuy et al., 1992) and dogs (Brown et al., 1994), while administration of L-NAME or L-NMMA caused enhanced bronchoconstriction in response to allergen (Persson et al., 1993; Mehta et al., 1997b), histamine (Nijkamp et al., 1993; Mehta et al., 1997a; Schuiling et al., 1998b) and bradykinin (Ricciardolo et al., 1994) in the guinea-pig and to bradykinin in mild asthmatics (Ricciardolo et al., 1996).

Using a guinea-pig model of acute allergic asthma, characterized by allergen-induced early and late asthmatic reactions, airway inflammation and AHR after both reactions (Santing et al., 1992; 1994), we have recently established that a deficiency of NO contributes to the increased ex vivo responsiveness of isolated perfused tracheae to methacholine and histamine after the early asthmatic reaction, at $6 \mathrm{~h}$ after inhalational challenge of the animals with ovalbumin aerosol (De Boer et al., 1996). Similarly, a deficiency of cNOS-derived NO was also found to contribute to the AHR to histamine in vivo after the early asthmatic reaction (Schuiling et al., 1998a,b), while restoration of NO activity, presumably by induction of iNOS during the late asthmatic reaction, contributed to the partial reversal of the AHR after this reaction (Schuiling et al., 1998a).

The cause of the allergen-induced NO deficiency after the early asthmatic reaction is presently unclear. Very recently, by investigating the effects of the $\mathrm{O}_{2}{ }^{-}$scavenger superoxide dismutase in perfused tracheal preparations from ovalbuminchallenged guinea-pigs, we demonstrated that this deficiency is not caused by depletion of NO due to its reaction with (inflammation-induced) superoxide anions (De Boer et al., 1998). In the present study, we examined the possibility of a reduced NO production due to limitation of substrate, by examining the effects of various concentrations of L-arginine on methacholine-induced constriction of perfused tracheal preparations from unchallenged control guinea-pigs and from ovalbumin-challenged animals obtained at $6 \mathrm{~h}$ after the challenge.

\section{Methods}

\section{Animals}

Outbred specified pathogen-free guinea-pigs (Charles River SAVO, Kiszlegg, Germany), weighing 500-800 g, were used in this study. All animals were actively IgE-sensitized to ovalbumin (OA) at 3 weeks of age as described by Van Amsterdam et al. (1989). In short, $0.5 \mathrm{ml}$ of an allergen solution containing $100 \mu \mathrm{g} \mathrm{ml}^{-1}$ ovalbumin and $100 \mathrm{mg} \mathrm{ml}^{-1} \mathrm{Al}(\mathrm{OH})_{3}$ in saline was injected intraperitoneally, while another $0.5 \mathrm{ml}$ was divided over seven intracutaneous injection sites in the proximity of lymphenodes in the paws, lumbar regions and the neck. The animals were used experimentally in weeks 4-8 after sensitization. The animals were group-housed in individual cages in climated animal quarters and given water and food ad libitum, while a 12-h on/off light cycle was maintained.
All protocols described in this study were approved by the University of Groningen Animal Health Committee.

\section{Allergen provocation}

Ovalbumin provocations were performed by inhalation of aerosolized solutions. The provocations were performed in a specially designed animal cage, in which the guinea-pigs could move freely (Santing et al., 1992). The volume of the cage was 91 , which ensured fast replacement of the air inside the cage with aerosol and vice versa. A DeVilbiss nebulizer (type 646, DeVilbiss, Somerset, PA, U.S.A.) driven by an airflow of 81 $\mathrm{min}^{-1}$ provided the aerosol required, with an output of $0.33 \mathrm{ml} \mathrm{min}{ }^{-1}$.

Allergen provocations were performed by inhalation of increasing aerosol concentrations of $0.5,1.0,3.0,5.0$ and $7.0 \mathrm{mg} \mathrm{ml} \mathrm{m}^{-1}$ ovalbumin in saline for $3 \mathrm{~min}$, separated by 10 min intervals. Allergen inhalations were discontinued when the first signs of respiratory distress were observed. No antihistaminic was needed to prevent the development of anaphylactic shock. Previous studies measuring pleural pressure changes in ovalbumin sensitized, permanently instrumented, unrestrained guinea-pigs have indicated that the allergen-induced early asthmatic reaction induced by this procedure is maximal within $20 \mathrm{~min}$ and lasts for up to $5 \mathrm{~h}$ (Santing et al., 1992; 1994).

\section{Tracheal perfusion}

Six hours after ovalbumin challenge, the guinea-pigs were sacrificed. Non challenged IgE-sensitized animals were used as controls. The animals were killed by a sharp blow on the head and exsanguinated. The tracheas were rapidly removed and placed in Krebs-Henseleit $(\mathrm{KH})$ solution $\left(37^{\circ} \mathrm{C}\right)$ of the following composition (mM): $\mathrm{NaCl} 117.50, \mathrm{KCl} 5.60, \mathrm{MgSO}_{4}$ 1.18, $\mathrm{CaCl}_{2} 2.50, \mathrm{NaH}_{2} \mathrm{PO}_{4} 1.28, \mathrm{NaHCO}_{3} 25.00$, D-glucose 5.50; gassed with $5 \% \mathrm{CO}_{2}$ and $95 \% \mathrm{O}_{2} ; \mathrm{pH} 7.4$.

The tracheas were prepared free of serosal connective tissue and cut into two halves of approximately $17 \mathrm{~mm}$ before mounting in a perfusion setup, as described previously (De Boer et al., 1996). To this aim, the tracheal preparations were attached at each side to stainless steel perfusion tubes fixed in a Delrin perfusion holder. The holder with the trachea was then placed in a water-jacketed organ bath $\left(37^{\circ} \mathrm{C}\right)$ containing $20 \mathrm{ml}$ of gassed KH (the serosal or extraluminal (EL) compartment). The lumen was perfused with recirculating $\mathrm{KH}$ from a separate $20 \mathrm{ml}$ bath (mucosal or intraluminal (IL) compartment) at a

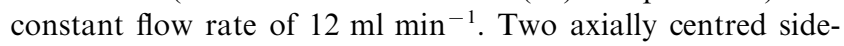
hole catheters connected with pressure transducers (TCXX,Viggo-Spectramed B.V., Bilthoven, The Netherlands) were situated at the distal and proximal ends of the trachealis to measure hydrostatic pressures $\left(\mathrm{P}_{\text {outlet }}\right.$ and $\mathrm{P}_{\text {inlet }}$, respectively). The signals were fed into a differential amplifier to obtain the difference between the two pressures $\left(\Delta \mathrm{P}=\mathrm{P}_{\text {inlet }}-\mathrm{P}_{\text {outlet }}\right)$, which was plotted on a flatbed chart recorder (BD 41, Kipp en Zonen, Delft, The Netherlands). $\Delta \mathrm{P}$ reflects the resistance of the tracheal segment to perfusion and is a function of the mean diameter of the trachea between the pressure taps (Munakata et al., 1989). The transmural pressure in the trachea was set at $0 \mathrm{~cm} \mathrm{H}_{2} \mathrm{O}$. At the perfusion flow rate used, a baseline $\Delta \mathrm{P}$ of 0.1 to $1.0 \mathrm{~cm} \mathrm{H}_{2} \mathrm{O}$ was measured, depending of the diameter of the preparation.

After a 45 min equilibration period with three washes with fresh KH (both IL and EL), $1 \mu \mathrm{M}$ isoprenaline was added to the EL compartment for maximal smooth muscle relaxation to assess basal tone. After three washes during at least $30 \mathrm{~min}$, the 
trachea was exposed to EL $40 \mathrm{mM} \mathrm{KCl}$ in $\mathrm{KH}$ to obtain a receptor-independent reference response. Subsequently, the preparation was washed four times with $\mathrm{KH}$ during $45 \mathrm{~min}$ until basal tone was reached and a cumulative concentration response curve (CCRC) was made with IL methacholine. When used, L-NAME $(100 \mu \mathrm{M})$ was applied to the IL reservoir, $45 \mathrm{~min}$ prior to agonist-addition. L-arginine $(0.3$, 1.0 and $5.0 \mathrm{mM})$ and $\mathrm{D}$-arginine $(5.0 \mathrm{mM})$ were added to the EL reservoir, $30 \mathrm{~min}$ prior to agonist addition.

\section{Data analysis}

To compensate for differences in baseline $\Delta \mathrm{P}$ and in $\Delta \mathrm{P}$ changes in response to contractile stimuli due to variation in resting internal diameter of the preparations used, IL responses of the tracheal tube preparations to methacholine were expressed as a percentage of the response induced by EL administration of $40 \mathrm{mM} \mathrm{KCl}$. The contractile effect of $10 \mathrm{~mm}$ methacholine (highest concentration) was defined as $\mathrm{E}_{\max }$. Using this $\mathrm{E}_{\max }$, the sensitivity to methacholine was evaluated as $\mathrm{pEC}_{50}\left(-\log _{10} \mathrm{EC}_{50}\right)$ value.

The results are expressed as means \pm s.e.mean. Statistical analysis was performed using the Student's $t$-test for unpaired

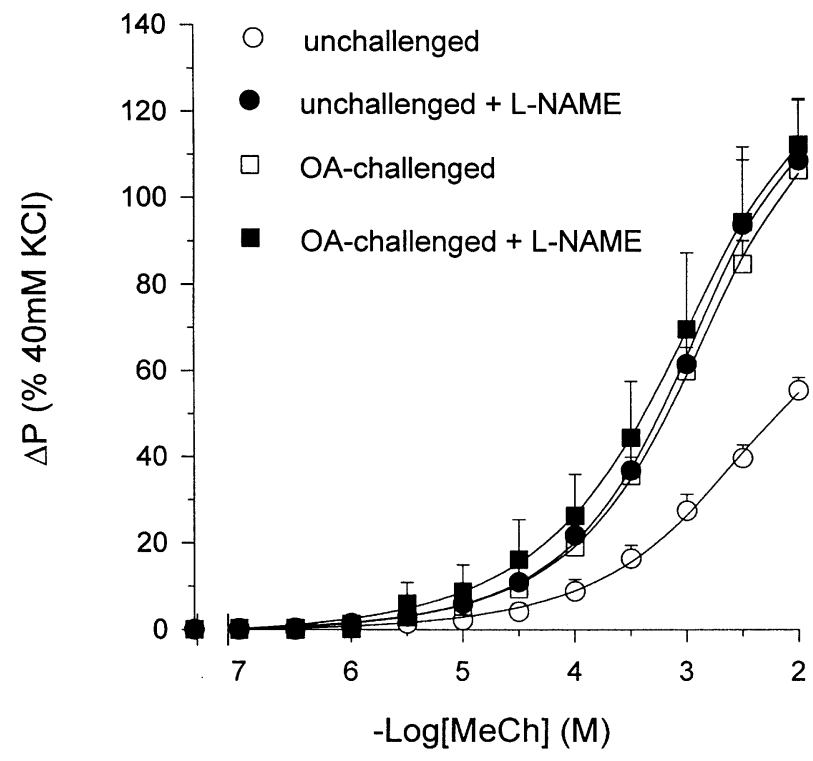

Figure 1 Methacholine (MeCh; IL)-induced constriction of intact perfused tracheae from unchallenged and ovalbumin (OA)-challenged guinea-pigs, in the absence and presence of $100 \mu \mathrm{M} \mathrm{L-NAME} \mathrm{(IL).}$ Results are means \pm s.e.mean of $6-12$ experiments. observations. Differences were considered statistically significant at $P<0.05$.

\section{Chemicals}

Histamine hydrochloride, ovalbumin (grade III), aluminum hydroxide, $(-)$-isoprenaline hydrochloride, L-arginine hydrochloride, D-arginine hydrochloride and $\mathrm{N}^{\omega}$-nitro-L-arginine methyl ester (L-NAME) were obtained from Sigma Chemical Co. (St. Louis, MO, U.S.A.) and methacholine chloride from Aldrich (Milwaukee, WI, U.S.A.).

\section{Results}

In perfused tracheal preparations of unchallenged guinea-pigs, the non-selective NOS inhibitor L-NAME $(0.1 \mathrm{mM}, \mathrm{IL})$ caused a significant 2.0 fold increase in the $\mathrm{E}_{\max }$ of IL methacholine $(P<0.01)$, without an effect on the sensitivity $\left(\mathrm{pEC}_{50}\right)$ to this agonist (Figure 1, Table 1).

In the ovalbumin-challenged group of animals, the $\Delta \mathrm{P}$ response to $\mathrm{KCl}$ was unchanged compared to the unchallenged control group (not shown). However, a 1.9 fold increase in the $\mathrm{E}_{\max }$ to IL methacholine was observed $(P<0.001)$, without a change in $\mathrm{pEC}_{50}$ (Figure 1, Table 1). This increase was not further enhanced in the presence of L-NAME (Figure 1, Table 1).

In the control preparations, $0.3 \mathrm{~mm}$ L-arginine (EL) caused a significant decrease of the $\mathrm{E}_{\max }$ to IL methacholine by approximately $40 \%(P<0.01)$, with no significant effect on the $\mathrm{pEC}_{50}$ for the agonist (Figure 2, Table 1). Higher concentrations of L-arginine (1.0 and 5.0 mM, EL) did not further decrease the responsiveness to methacholine, although there was a tendency to a gradually reduced sensitivity to the agonist (Figure 2, Table $1)$. In the presence of the inactive enantiomer D-arginine (5.0 mM, EL) the responsiveness to IL methacholine remained unaltered (Figure 2, Table 1).

In tracheae obtained from guinea-pigs at $6 \mathrm{~h}$ after allergen challenge, 1.0 and $5.0 \mathrm{mM}$ L-arginine (EL) caused a significant, dose-dependent decrease of the $\mathrm{E}_{\max }$ of IL methacholine, by $33 \%$ $(P<0.01)$ and $65 \%(P<0.001)$, respectively (Figure 3, Table 1$)$. In addition, there was a small but significant decrease in the $\mathrm{pEC}_{50}$ for methacholine in the presence of $1.0 \mathrm{mM} \mathrm{L}$-arginine, which did not change further in the presence of $5.0 \mathrm{~mm}$ of the NOS substrate (Table 1). In the presence of $5.0 \mathrm{~mm} \mathrm{~L}$-arginine, the responsiveness of the challenged tracheal preparations to methacholine was very similar to that of the unchallenged control preparations (Figures 2 and 3, Table 1). As in the control preparations, D-arginine had no effect on the responsiveness to

Table 1 Effects of L-NAME and L- and D-arginine on the responsiveness to methacholine of intact perfused tracheae from unchallenged and ovalbumin (OA)-challenged guinea-pigs

\begin{tabular}{|c|c|c|c|c|}
\hline & \multicolumn{2}{|c|}{ Unchallenged } & \multicolumn{2}{|c|}{ OA-challenged } \\
\hline & $p E C_{50}(-\log \mathrm{M})$ & $E_{\max }(\% \mathrm{KCl})$ & $p E C_{50}(-\log \mathrm{M})$ & $E_{\max }(\% \mathrm{KCl})$ \\
\hline Vehicle & $3.01 \pm 0.11$ & $55.5 \pm 3.1$ & $3.14 \pm 0.07$ & $106.4 \pm 3.8^{+++}$ \\
\hline L-NAME & & & & \\
\hline $0.1 \mathrm{~mm}$ & $3.16 \pm 0.09$ & $108.7 \pm 14.3^{* *}$ & $3.15 \pm 0.24$ & $112.4 \pm 10.4$ \\
\hline L-arginine & & & & \\
\hline $0.3 \mathrm{~mm}$ & $3.33 \pm 0.40$ & $33.0 \pm 4.7 * *$ & N.D. & N.D. \\
\hline $1.0 \mathrm{mM}$ & $2.84 \pm 0.10$ & $32.9 \pm 3.4^{* * *}$ & $2.79 \pm 0.04^{*}$ & $71.8 \pm 6.6^{* * /+++}$ \\
\hline $5.0 \mathrm{mM}$ & $2.68 \pm 0.13$ & $31.1 \pm 7.5^{* *}$ & $2.82 \pm 0.21$ & $36.8 \pm 7.1^{* * *}$ \\
\hline $\mathrm{D}$-arginine & & & & \\
\hline $5.0 \mathrm{mM}$ & $3.03 \pm 0.16$ & $57.5 \pm 10.6$ & $3.28 \pm 0.35$ & $99.9 \pm 5.9^{+}$ \\
\hline
\end{tabular}

Results are means \pm s.e.mean of $3-15$ experiments. Statistical analysis: $* P<0.05, * * P<0.01$ and $* * * P<0.001$ compared to vehicle; ${ }^{+} P<0.05,{ }^{+++} P<0.001$ compared to unchallenged. N.D., not determined. 
methacholine in the allergen-challenged preparations (Figure 3, Table 1).

Both in the control preparations and in the preparations of allergen-challenged animals, L-NAME and L- and D-arginine had no effect on basal airway tone (not shown).

\section{Discussion}

Using the nonselective NOS inhibitor L-NAME, we confirmed our previous finding (De Boer et al., 1996) that methacholineinduced constriction of guinea-pig tracheal tube preparations from unchallenged guinea-pigs is functionally antagonized by

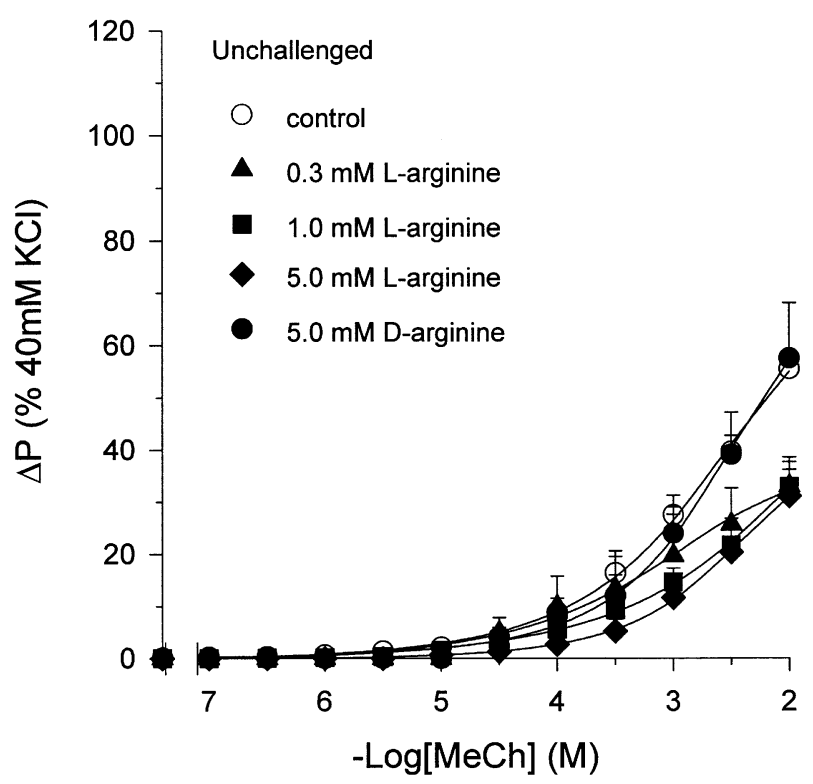

Figure 2 Methacholine (MeCh; IL)-induced constriction of intact perfused tracheae from unchallenged guinea-pigs in the absence (control) and presence of $0.3,1.0$ and $5.0 \mathrm{~mm}$ L-arginine (EL), and $5 \mathrm{mM}$ D-arginine (EL). Results are means \pm s.e.mean of $3-11$ experiments.

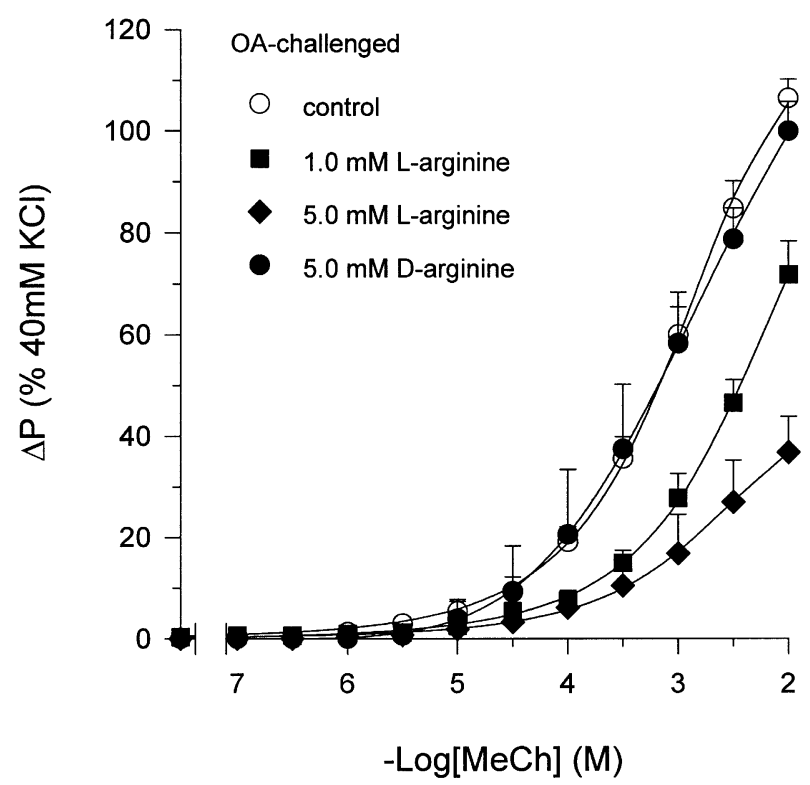

Figure 3 Methacholine (MeCh; IL)-induced constriction of intact perfused tracheae from ovalbumin (OA)-challenged guinea-pigs in the absence (control) and presence of 1.0 and $5.0 \mathrm{mM} \mathrm{L}$-arginine (EL), and $5 \mathrm{~mm}$ D-arginine (EL). Results are means \pm s.e.mean of $3-15$ experiments. agonist-induced cNOS-derived NO. In the present study, it was also demonstrated that EL administration of the NO precursor arginine significantly reduced the responsiveness to methacholine in a stereoselective manner in these preparations, indicating that the production of agonist-induced endogenous NO may be enhanced by supplementation of substrate, and that the supply of L-arginine is a rate-limiting factor for cNOS activity in normal airways. This is in line with recent observations that oral administration (Kharitonov et al., 1995) as well as inhalation (Sapienza et al., 1998) of L-arginine cause an increase in exhaled NO in healthy human subjects.

The tracheal responsiveness to methacholine was markedly enhanced at $6 \mathrm{~h}$ after allergen challenge. As also found previously (De Boer et al., 1996), the observed airway hyperreactivity was closely mimicked by the administration of L-NAME to unchallenged control preparations, while, in addition, the hyperreactive preparations were unresponsive to the NOS inhibitor, indicating that a deficiency of agonistinduced NO is a major determinant of the observed hyperreactivity. The enhanced responsiveness to methacholine was completely reversed in the presence of $5 \mathrm{mM}$ L-arginine, which indicates that limitation of substrate may underlie the deficiency of NO and subsequent AHR to methacholine after the early asthmatic reaction.

Different mechanisms could account for a limitation of Larginine for cNOS activity after allergen challenge. First, recent observations in rat alveolar macrophages have indicated that polycationic proteins including eosinophil-derived major basic protein (MBP), which is released during the allergic asthmatic reaction and involved in the development of AHR (Gleich et al., 1988), may cause inhibition of cellular uptake of L-arginine by specific cationic amino acid transporters (Hirschmann et al., 1998). Using intact perfused guinea-pig tracheae, we recently demonstrated that the polycationic MBP analogue poly-L-arginine may indeed cause NO deficiency and AHR to methacholine in these preparations (Meurs et al., 1999).

Secondly, the bioavailability of L-arginine could be reduced by enhanced arginase activity in the airways. Arginase, which hydrolyzes L-arginine to L-ornithine and urea, is constitutively expressed in many cells throughout the body, including the lung (Aminlari \& Vaseghi, 1992). Studies in murine bone marrow-derived macrophages have recently indicated that the expression of arginase may be selectively enhanced by $\mathrm{T}_{\mathrm{H}} 2$ lymphocyte-derived cytokines (interleukin4 and interleukin-10), which are involved in allergic inflammation, thus causing reduced NO production in these cells due to substrate depletion (Corraliza et al., 1995). Enhanced expression of inducible (type II) arginase by cytokines or lipopolysaccharide has also been observed in other cells, and has been proposed to be an important regulatory mechanism of NOS activity (Wang et al., 1995; Gotoh et al., 1996). Accordingly, in alveolar macrophages it has recently been shown that inhibition of arginase by $\mathrm{N}^{\omega}$ hydroxy-D,L-indospicine, a potent and specific arginase inhibitor (Vadon et al., 1996), causes a shift of L-arginine utilization to the NOS pathway (Hey et al., 1997).

Other hypothetical mechanisms that might be involved in L-arginine limitation for NOS activity are a reduced Lcitrulline-L-arginine recycling (Chakder \& Rattan, 1997), as well as a reduced affinity of NOS for the substrate. The latter idea would be in line with the reduced sensitivity to exogenous L-arginine in the challenged preparations, as indicated by the partial effect of $1.0 \mathrm{mM}$ L-arginine in challenged airways compared to the full depression of the methacholine response in control preparations. 
The observation that the enhanced methacholine reactivity in the NO-deficient tracheae at $6 \mathrm{~h}$ after allergen challenge can be fully reversed by L-arginine suggests that only the activity and not the protein expression of cNOS is reduced after allergen challenge. In addition, in a similar in vitro setting, we recently demonstrated that the deficiency of NO in hyperreactive tracheae is not caused by its possible reaction with superoxide anion in the airways (De Boer et al., 1998).

Different studies have indicated that the present ex vivo findings are relevant to the development of airway hyperreactivity in vivo. Thus, using the same conscious and unrestrained guinea-pig model of asthma, we have recently demonstrated that inhalation of the non-selective NOS inhibitor L-NAME, but not a selective dose of the specific iNOS inhibitor aminoguanidine, caused AHR to histamine before allergen challenge, indicating that cNOS-derived NO counteracts histamine-induced bronchoconstriction under basal conditions (Schuiling et al., 1998a,b). At $6 \mathrm{~h}$ after allergen challenge, both L-NAME and aminoguanidine had no effect on the allergeninduced AHR to histamine at this time point, indicating that a deficiency of (cNOS-derived) NO may contribute the AHR after the early asthmatic reaction (Schuiling et al., 1998a,b). In addition, by using aminoguanidine, it was pharmacologically established that bronchodilating iNOS-derived NO may contribute to the partial reversal of the AHR after the allergen-induced late asthmatic reaction (Schuiling et al., 1998a). In the same study, iNOS-derived NO also proved to have detrimental effects on airway reactivity by promoting airway inflammation and epithelial damage, indicating its dualistic role in the airways. In line with these observations, several studies have demonstrated the induction of iNOS mRNA, immunoreactivity and enzyme activity during (the time span of) the allergen-induced late asthmatic reaction (Yeadon \& Price, 1995; Yan et al., 1995; Renzi et al., 1997).

Very interestingly, evidence for a deficiency of cNOSderived NO modulating airway reactivity was recently also found in patients with severe asthma treated with corticosteroids, which suppresses the expression of iNOS (Ricciardolo et al., 1997). Thus, while the airway reactivity to bradykinin (and to methacholine) could be significantly increased by inhalation of L-NMMA in patients with mild asthma (Ricciardolo et al., 1996), a similarly enhanced AHR to bradykinin present in severe asthmatics was insensitive to the NOS inhibitor, indicating that a deficiency of NO contributed to the enhanced airway responsiveness in these patients. Preliminary evidence by the same authors suggests that this deficiency may indeed be induced by allergen challenge (Ricciardolo et al., 1999).

Also of interest is the recent finding by Gaston et al. (1998) that S-nitrosothiol concentrations in tracheal aspirates of children with near-fatal asthma were lower than those in nonasthmatic children. S-nitrosothiols are relatively stable NO adducts that may be formed by the reaction of NO with reduced thiols, such as reduced glutathion and cysteincontaining peptides and proteins (Gaston et al., 1994). It has been reported that exogenously applied S-nitrosothiols may cause airway smooth muscle relaxation and bronchodilation in different species, including guinea-pigs (Jansen et al., 1992; Bannenberg et al., 1995). However, concentrations of endogenous S-nitrosothiols and their functional role in guinea-pig airways remain to be established.

A deficiency of cNOS-derived NO causing AHR to histamine was recently also demonstrated in guinea-pigs with a respiratory parainfluenza type 3 infection (Folkerts et al., 1995). As in the present study, the enhanced airway reactivity could be reversed by L-arginine, indicating that a deficiency of the NOS substrate may similarly be involved in virus-induced AHR. Moreover, in allergic asthmatics who were experimentally infected with rhinovirus-16, the increase in the airway reactivity to histamine was inversely correlated with the NO level in exhaled air, indicating the protective role of endogenous NO in virus-induced AHR (De Gouw et al., 1998).

Since L-arginine was shown to reverse the allergen-induced AHR after the early asthmatic reaction as well as virusinduced AHR, it could have therapeutic potential in patients with asthma. However, since L-arginine may also amplify the inflammatory effects of iNOS-derived NO present in most patients (Sapienza et al., 1998), its usefulness remains to be established.

In conclusion, our data demonstrate that a deficiency of endogenous NO contributes to the allergen-induced AHR to methacholine after the early asthmatic reaction, which can be reversed by exogenous L-arginine. This indicates that limitation of substrate may cause a reduced cNOS activity and subsequent AHR after the acute asthmatic response.

This study was financially supported by Glaxo-Wellcome Nederland B.V.

\section{References}

AMINLARI, M. \& VASEGHI, T. (1992). Arginase distribution in tissues of domestic animals. Comp. Biochem. Physiol., 103B, $385-389$.

ASANO, K., CHEE, C.B.E., GASTON, B., LILly, C.M., GERARD, C., DRAZEN, J.M. \& STAMLER, J.S. (1994). Constitutive and inducible nitric oxide synthase gene expression, regulation, and activity in human lung epithelial cells. Proc. Natl. Acad. Sci. U.S.A., 91, $10089-10093$.

BANNENBERG, G., XUE, J., ENGMAN, L., COTGReAVE, I., MOLDÉUS, P. \& RYRFELDT, Å. (1995). Characterization of bronchodilator effects and fate of S-nitrosothiols in the isolated perfused and ventilated guinea pig lung. J. Pharmacol. Exp. Ther., 272, $1238-1245$.

BARNES, P.J. \& BELVISI, M.G. (1993). Nitric oxide and lung disease. Thorax, 48, $1034-1043$.

BARNES, P.J. \& LIEW, F.Y. (1995). Nitric oxide and asthmatic inflammation. Immunol. Today, 16, $128-130$.
BOOIJ-NOORD, H., ORIE, N.G.M. \& DE VRIES, K. (1971). Immediate and late bronchial obstructive reactions to inhalation of housedust and protective effects of disodium cromoglycate and prednisolone. J. Allergy Clin. Immunol., 48, 344-354.

BROWN, R.H., ZERHOUNI, E.A. \& HIRSHMAN C.A. (1994). Reversal of bronchoconstriction by inhaled nitric oxide. Histamine versus methacholine. Am. J. Respir. Crit. Care Med., 150, 233-237.

CHAKDER, S. \& RATTAN, S. (1997). L-arginine deficiency causes suppression of nonadrenergic noncholinergic nerve-mediated smooth muscle relaxation: role of L-citrulline recycling. $J$. Pharmacol. Exp. Ther., 282, $378-384$.

COCKCROFT, D.W., RUFFIN, R.E., DOLOVICH, J. \& HARGREAVE, F.E. (1977). Allergen-induced increase in non-allergic bronchial reactivity. Clin. Allergy, 7, 503-513. 
CORRALIZA, I.M., SOLER, G., EICHMANN, K. \& MODOLELl, M. (1995). Arginase induction by suppressors of nitric oxide synthesis (IL-4, IL-10 and PGE $_{2}$ ) in murine bone-marrowderived macrophages. Biochem. Biophys. Res. Commun., 206, $667-673$

DE BOER, J., MEURS, H., COERS, W., KOOPAL, M., BOTTONE, A.E., VISSER, A.C., TIMENS, W. \& ZAAGSMA, J. (1996). Deficiency of nitric oxide in allergen-induced airway hyperreactivity to contractile agonists after the early asthmatic reaction. An ex vivo study. Br. J. Pharmacol., 116, 1109-1116.

DE BOER, J., POUW, F.M., ZAAGSMA, J. \& MEURS, H. (1998). Effects of endogenous superoxide anion and nitric oxide on cholinergic constriction of normal and of hyperreactive guinea-pig airways. Am. J. Respir. Crit. Care Med., 158, 1784-1789.

DE GOUW, H.W.F.M., GRÜNBERG, K., SCHOT, R., KROES, A.C.M., DICK, E.C. \& STERK, P.J. (1998). Relationship between exhaled nitric oxide and airway hyperresponsiveness following experimental rhinovirus infection in asthmatic subjects. Eur. Respir. J., 11, $126-132$

DE MONCHY, J.G.R., KAUFFMAN, H.F., VENGE, P., KOËTER, G.H., JANSEN, H.M., SLUITER, H.J. \& DE VRIES, K. (1985). Bronchoalveolar eosinophilia during allergen-induced late asthmatic reactions. Am. Rev. Respir. Dis., 131, 373-376.

DJUKANOVIC, R., ROCHE, W.R., WILSON, J.W., BEASLEY, C.R.W., TWENTYMAN, O.P. \& HOWARTH, P.H. (1990). Mucosal inflammation in asthma. Am. Rev. Respir. Dis., 142, 434-457.

DUPUY, P.M., SHORE, P.A., DRAZEN, J.M., FROSTELL, C., HILL, W.A. \& ZAPOL, W.M. (1992). Bronchodilator action of inhaled nitric oxide in guinea-pigs. J. Clin. Invest., 90, $421-428$.

DURHAM, S.R., CRADDOCK, C.F., COOKSON, W.O. \& BENSON, M.K. (1988). Increases in airway responsiveness to histamine precede allergen-induced late asthmatic responses. J. Allergy Clin. Immunol., 82, $764-770$.

FIGINI, M., EMANUELI, C., BERTRAND, C., SICUTERI, R., REGOLI, D \& GEPPETTI, P. (1997). Differential activation of the epithelial and smooth muscle NK, receptors by synthetic tachykinin agonists in guinea-pig trachea. Br. J. Pharmacol., 121, 773-781.

FIGINI, M., RICCIARDOLO, F.L.M., JAVDAN, P., NIJKAMP, F.P., EMANUELI, C., PRADELLES, P., FOLKERTS, G. \& GEPPETTI, P. (1996). Evidence that epithelium-derived relaxing factor released by bradykinin in the guinea-pig trachea is nitric oxide. Am. J. Respir. Crit. Care Med., 153, $918-923$.

FILEP., J.G., BATTISTINI, B. \& SIRIOS, P. (1993). Induction of endothelin-1 of epithelium-dependent relaxation of guinea-pig trachea in vitro: role for nitric oxide. Br. J. Pharmacol., 109, 637644.

FISCHER, A., MUNDEL, P., PREISSLER, U., PHILIPPIN, B. \& KUMMER, W. (1993). Nitric oxide synthase in guinea-pig lower airway innervation. Neurosci. Lett., 149, 157-160.

FLAK, T.A. \& GOLDMAN, W.E. (1996). Autotoxicity of nitric oxide in airway disease. Am. J. Respir. Crit. Care Med., 154, S202-S206.

FOLKERTS, G. VAN DER LINDE, H.J. \& NIJKAMP, F.P. (1995). Virus-induced airway hyperresponsiveness in guinea-pigs is related to a deficiency in nitric oxide. J. Clin. Invest., 95, 26-30.

FORESTERMANN, U., SCHMIDT, H.H., POLLOCK, J.S., SHENG, H., MITCHELL, J.A., WARNER. T.D., NAKANE, M. \& MURAD, F. (1991). Isoforms of nitric oxide synthase. Characterization and purification from different cell types. Biochem. Pharmacol., 42, $1849-1857$.

GASTON, B., DRAZEN, J.M., LOSCALZO, J. \& STAMLER, J.S. (1994). The biology of nitrogen oxides in the airways. Am. J. Respir. Crit. Care Med., 149, $538-551$

GASTON, B., SEARS, S., WOODS, J., HUNT, J., PONAMAN, M., McMAHON, T. \& STAMLER, J.S. (1998). Bronchodilator Snitrosothiol deficiency in asthmatic respiratory failure. Lancet, 351, $1317-1319$.

GLEICH, G.J., FLAVAHAN, N.A., FUJISAWA, T. \& VANHOUTTE, P.M. (1988). The eosinophil as a mediator of damage to respiratory epithelium: A model for bronchial hyperreactivity. J. Allergy Clin. Immunol., 81, 776-781.

GOTOH, T., SONOKI, T., NAGASAKI, A., TERADA, K., TAKIGUCHI, A. \& MORI, M. (1996). Molecular cloning of cDNA for nonhepatic mitochondrial arginase (arginase II) and comparison of its induction with nitric oxide synthase in a murine macrophage-like cell. FEBS Lett., 395, $119-122$.

GRUETTER, C.A., CHILDERS, C.C., BOSSERMAN, M.K., LEMKE, S.M., BALL, J.G. \& VALENTOVIC, M.A. (1989). Comparison of relaxation induced by glyceryl trinitrate, isosorbide dinitrate and sodium nitroprusside in bovine airways. Am. Rev. Respir. Dis., 139, $1192-1197$
HAMID, Q., SPRINGALL, D.R., RIVEROS-MORENO, V., CHANEZ, P., HOWARTH, P., REDINGTON, A., BOUSQUET, J., GODARD, PH., HOLGATE, S \& POLAK, J.M. (1993). Induction of nitric oxide synthase in asthma. Lancet, 342, 1510-1513.

HEY, C., BOUCHER, J.-L., VADON-LE GOFF, S., KETTERER, G., WESSLER, I. \& RACKÉ, K. (1997). Inhibition of arginase in rat and rabbit alveolar macrophages by $\mathrm{N}^{\omega}$-hydroxy-D,L-indospicine, effects on L-arginine utilization by nitric oxide synthase. $\mathrm{Br}$. J. Pharmacol., 121, 395-400.

HIRSCHMANN, J., HEY, C., HAMMERMANN, J.G., FOLKERTS, J.G., NIJKAMP, F.P., GLEICH, G.J., WESSLER, I. \& RACKÉ , K. (1998). Inhibition of L-arginine transport in rat and guinea-pig alveolar macrophages $(\mathrm{AM} \phi)$ by poly-cationic peptides. Br. J. Pharmacol., 123, 177P.

JANSEN, A., DRAZEN, J., OSBORNE, J.A., BROWN, R., LOSCALZO, J. \& STAMLER, J.S. (1992). The relaxant properties in guinea-pig airways of S-nitrosothiols. J. Pharmacol. Exp. Ther., 261, $154-$ 160 .

KACMAREK, R.M., RIPPLE, R, COCKRILL, B.A., BLOCH, K.J, ZAPOL, W.M. \& JOHNSON, D.C. (1996). Inhaled nitric oxide. A bronchodilator in mild asthmatics with methacholine-induced bronchospasm. Am. J. Respir. Crit. Care Med., 153, 128-135.

KHARITONOV, S.A., LUBEC, G., LUBEC, B., HJELM, M. \& BARNES, P.J. (1995). L-arginine increases exhaled nitric oxide in normal human subjects. Clin. Sci., 88, $135-139$.

KOBZIK, L., BREDT, D.S., LOWENSTEIN, C.J., DRAZEN, J., GASTON, B., SUGARBAKER, D. \& STAMLER, J.S. (1993). Nitric oxide synthase in human and rat lung: immunocytochemical and histochemical localization. Am. J. Respir. Cell. Mol. Biol., 9, $371-377$.

KUO, H.P., LIU, S. \& BARNES, P.J. (1992). The effect of endogenous nitric oxide on neurogenic plasma exudation in guinea-pig airways. Eur. J. Pharmacol., 221, 385-388.

LILLY, C.M., STAMLER, J.S., GASTON, B., MECKEL, C., LOSCALZO, J. \& DRAZEN, J.M. (1993). Modulation of vasoactive intestinal peptide pulmonary relaxation by NO in tracheally superfused guinea-pig lungs. Am. J. Physiol., 265, L410-L415.

MEHTA, S., DRAZEN, J.M. \& LILLY, C.M. (1997a). Endogenous nitric oxide and allergic bronchial hyperresponsiveness in guinea-pigs. Am. J. Physiol., 273, L656-L662.

MEHTA, S., LILLY, C.M., ROLLENHAGEN, JE, HALEY, K.J. ASANO, K. \& DRAZEN, J.M. (1997b). Acute and chronic effects of allergic airway inflammation on pulmonary nitric oxide production. Am. J. Physiol., 272, L124-L131.

MEURS, H., SCHUURMAN, F.E., DUYVENDAK, M. \& ZAAGSMA, J. (1999). Deficiency of nitric oxide in polycation-induced airway hyperreactivity. Br. J. Pharmacol., 126, 559-562.

MUNAKATA, M., HUANG, I., MITZNER, W. \& MENKES, H. (1989). Protective role of epithelium in the guinea-pig airway. J. Appl. Physiol., 66, $1547-1552$.

NIJKAMP, F.P., VAN DER LINDE, H.J. \& FOLKERTS, G. (1993). Nitric oxide synthesis inhibitors induce airway hyperresponsiveness in the guinea-pig in vivo and in vitro. Am. Rev. Respir. Dis., 148, $727-734$.

PERSSON M.G., FRIBERG, S.G., HEDQVIST, P. \& GUSTAFSSON, L.E. (1993). Endogenous nitric oxide counteracts antigen-induced bronchoconstriction. Eur. J. Pharmacol., 249, R7-R8.

RENZI, P.M., SEBASTIAO, N., AL ASAAD, A.S., GIAID, A. \& HAMID, Q. (1997). Inducible nitric oxide synthase mRNA and immunoreactivity in the lungs of rats eight hours after antigen challenge. Am. J. Respir. Cell Mol. Biol., 17, 36-40.

RICCIARDOLO, F.L.M., DI MARIA, G.U., MISTRETTA, A., SAPIENZA, M.A. \& GEPPETTI, P. (1997). Impairment of bronchoprotection by nitric oxide in severe asthma. Lancet, 350, $1297-1298$.

RICCIARDOLO, F.L.M., GEPPETTI, P., MISTRETTA, A., NADEL, J.A., SAPIENZA, M.A., BELLOFIORE, S. \& DI MARIA, G.U. (1996). Randomised double-blind placebo-controlled study of the effect of inhibition of nitric oxide synthesis in bradykinin-induced asthma. Lancet, 348, $374-377$.

RICCIARDOLO, F.L.M., NADEL, J.A., YOISHIHARA, S. \& GEPPETTI, P. (1994). Evidence for reduction of bradykinin-induced bronchoconstriction in guinea-pigs by release of nitric oxide. Br. J. Pharmacol., 113, $1147-1152$.

RICCIARDOLO, F.L.M. TIMMERS, M.C. GEPPETTI, P. \& STERK, P.J. (1999). Effect of nitric oxide synthesis inhibition on allergeninduced airway hyperresponsiveness to bradykinin in allergic asthma. Am. J. Respir. Crit. Care Med., 159, A868. 
SANTING, R.E., MEURS, H., VAN DER MARK, TH.W., REMIE, R., OOSTEROM, W.C., BROUWER, F. \& ZAAGSMA, J. (1992). A novel method to assess airway function parameters in chronically instrumented, unrestrained guinea-pigs. Pulm. Pharmacol., 5, $265-272$.

SANTING, R.E., OLYMULDER, C.G., ZAAGSMA, J. \& MEURS, H. (1994). Relationships among allergen-induced early and late phase airway obstructions, bronchial hyperreactivity, and inflammation in conscious, unrestrained guinea-pigs. J. Allergy Clin. Immunol., 93, $1021-1030$.

SAPIENZA, M.A., KHARITONOV, S.A., HORVATH, I., CHUNG, K.F. \& BARNES, P.J. (1998). Effect of inhaled L-arginine on exhaled nitric oxide in normal and asthmatic subjects. Thorax, 53, $172-$ 175.

SCHUILING, M., MEURS, H., ZUIDHOF, A.B., VENEMA, N. \& ZAAGSMA, J. (1998a). Dual action of iNOS-derived nitric oxide in allergen-induced airway hyperreactivity in conscious, unrestrained guinea-pigs. Am. J. Respir. Crit. Care Med., $1581442-$ 1449.

SCHUILING, M., ZUIDHOF, A.B., BONOUVRIE, A.A., VENEMA, N., ZAAGSMA, J. \& MEURS, H. (1998b). Role of nitric oxide in the development and partial reversal of allergen-induced airway hyperreactivity in conscious, unrestrained guinea-pigs. $\mathrm{Br} . J$. Pharmacol., 123, 1450-1456.
VADON, S., CUSTOT, J., BOUCHER, J-L. \& MANSUY, D. (1996). Synthesis and effects on arginase and nitric oxide synthase of two novel analogues of $\mathrm{N}^{\omega}$-hydroxyarginine, $\mathrm{N}^{\omega}$-hydroxyindospicine and $p$-hydroxyamidinophenylalanine. J. Chem. Soc., Perkin Trans., 1, 645-648.

VAN AMSTERDAM, R.G.M., BROUWER, F. \& ZAAGSMA, J. (1989). Analysis of the $\beta$-adrenoceptor mediated inhibition of IgG- and IgE-dependent guinea-pig anaphylactic tracheal smooth muscle contraction. Agents Actions, 26, $48-51$.

WANG, W.W., JENKINSON, C.P., GRISCAVAGE, J.M., KERN, R.M., ARABOLOS, N.S., BYRNS, R.E., CEDERBAUM, S.D. \& IGNARRO, L.J. (1995). Co-induction of arginase and nitric oxide synthase in murine macrophages activated by lipopolysaccharide. Biochem. Biophys. Res. Commun., 210, $1009-1016$.

YAN, Z.-Q., HANSSON, G.K., SKOOGH, B.-E. \& LOTVALL, J.O. (1995). Induction of nitric oxide synthase in a model of allergic occupational asthma. Allergy, 50, $760-764$.

YEADON, M. \& PRICE, R. (1995). Induction of calcium-independent nitric oxide synthase by allergen challenge in sensitized rat lung in vivo. Br. J. Pharmacol., 116, 2545-2546.

(Received July 21, 1999

Revised August 11, 1999 Accepted August 16, 1999) 